\title{
PENGARUH KOMPENSASI DAN KOMPETENSI TERHADAP KINERJA KARYAWAN PT. HERFINTA AEK BATU KECAMATAN TORGAMBA KABUPATEN LABUHANBATU SELATAN
}

\author{
DESMAWATY HASIBUAN \\ Dosen Tetap Sekolah Tinggi Ilmu Ekonomi (Stie) Labuhanbatu
}

\begin{abstract}
ABSTRAK
Kompensasi merupakan suatu bentuk biaya yang harus dikeluarkan oleh perusahaan dengan harapan bahwa perusahaan akan memperoleh imbalan dalam bentuk prestasi kerja dari karyawannya. Kompensasi diharapkan mampu merangsang atau memotivasi semangat kerja karyawan sehingga dapat memberikan kinerja terbaiknya untuk perusahaan yang akan berdampak pada kepuasan kerja dan kualitas kerja. Tujuan penelitian ini adalah untuk mengetahui pengaruh kompensasi dan kompetensi secara simultan berpengaruh Terhadap kinerja karyawan PT. Herfinta Aek Batu Kecamatan Torgamba Kabupaten Labuhanbatu Selatan baik secara parsial maupun simultan. Sampel penelitian ini adalah seluruh karyawan PT. Herfinta Aek batu Kecamatan Torgamba Kabupaten labuhanbatu Selatan. Penentuan jumlah sampel menggunakan rumus slovin. Hasil penelitian menunjukkan bahwaVariabel Kompensasi secara parsial memiliki pengaruh paling dominan Terhadap kinerja karyawan, Variabel Kompetensi secara parsial memilik pengaruh Terhadap kinerja karyawan. Variabel Kompensasi dan Kompetensi secara serempak memiliki pengaruh Terhadap kinerja karyawan.
\end{abstract}

\section{Kata Kunci : Kompensasi, Kompetensi dan Kinerja.}

\section{PENDAHULUAN}

Sumber daya manusia memegang peranan penting dalam suatu organisasi atau instansi karena sumber daya manusia mempunyai kedudukan yang sentral dalam setiap kegiatan instansi. Dalam melaksanakan program, setiap instansi selalu diarahkan untuk mencapai tujuannya.

Setiap organisasi, baik organisasi publik maupun organisasi perusahaan sangat membutuhkan karyawan yang benar-benar memiliki keterampilan dan keahlian yang sesuai dengan bidang kerjanya, sehingga nantinya dapat menguasai tugas dan tanggung jawab yang dibebankan kepadanya. Melihat pentingnya peran sumber daya manusia manusia dalam organisasi, maka tidaklah berlebihan jika dikatakan bahwa karyawan adalah aset paling penting yang berdampak pada kesejahteraan organisasi dibandingkan dengan sumber daya lain.

Faktor pendorong penting yang menyebabkan manusia bekerja adalah adanya kebutuhan dalam diri manusia yang harus dipenuhi. Dengan kata lain, berangkat dari keinginan untuk memenuhi kebutuhan hidup, manusia bekerja dengan menjual tenaga, pikiran dan juga waktu yang dimilikinya kepada organisasi dengan harapan mendapatkan imbalan yang sesuai dengan keinginannya.

Salah satu faktor untuk yang mempengaruhi tingkat keberhasilan suatu perusahaan adalah kinerja karyawannya. Kinerja karyawan adalah apa yang dilakukan atau tidak dilakukan oleh 
karyawan yang meliputi kuantitas dari hasil, kualitas dari hasil, ketepatan waktu dari hasil, kehadiran dan kemampuan bekerja sama.

Persoalan karyawan disebabkan oleh masalah yang beraneka ragam, misalnya kompensasi yang tidak sesuai dengan keinginan karyawan dan kurangnya kompetensi yang dimiliki oleh karyawan itu sendiri.

Kompensasi merupakan suatu bentuk biaya yang harus dikeluarkan oleh perusahaan dengan harapan bahwa perusahaan akan memperoleh imbalan dalam bentuk prestasi kerja dari karyawannya. Kompensasi diharapkan mampu merangsang atau memotivasi semangat kerja karyawan sehingga dapat memberikan kinerja terbaiknya untuk perusahaan yang akan berdampak pada kepuasan kerja dan kualitas kerja.

Kompensasi pada dasarnya dikelompokkan menjadi dua, yaitu kompensasi finansial dan nonfinansial. Kompensasi finansial dapat diberikan secara langsung dan tidak langsung. Kompensasi finansial secara langsung dapat berupa gaji, upah dan insentif, sedangkan kompensasi finansial secara tidak langsung dapat berupa asuransi kesehatan, asuransi jiwa dan dana pensiun. Kompensasi nonfinansial dapat berupa pekerjaan yang menarik dan lingkungan kerja yang nyaman.

Kompensasi merupakan hal yang sensitif bila dikaitkan dengan kelayakan dalam memenuhi kebutuhan, apalagi semakin besarnya tingkat kebutuhan saat ini sehingga gaji yang diberikan masih dirasa kurang cukup. Pemberian kompensasi yang adil sangat dibutuhkan oleh setiap karyawan karena dengan adanya pembagian kompensasi secara adil karyawan merasa dihargai atas usaha yang dicurahkan untuk perusahaan. Kompensasi yang diberikan oleh PT. Herfinta Aek Batu yaitu berupa gaji, tunjangan-tunjangan dan fasilitas yang mendukung pekerjaan.

Kompensasi dalam bentuk tunjangan tambahan penghasilan yang diberikan oleh PT. Herfinta Aek Batu sebenarnya dirasa cukup oleh karyawan, hanya saja waktu pemberiannya yang dilakukan masih sering tidak tepat waktu ,menyebabkan karyawan tidak dapat memenuhi kebutuhannya dengan segera.

Selain kompensasi, kompetensi juga merupakan faktor penting yang mempengaruhi kinerja karyawan. Kompetensi meliputi aspek pengetahuan, keterampilan, sikap dan perilaku karyawan . Pengertian kompetensi juga dapat dipadukan dengan soft skill, hard skill, social skill dan mentality skill. Soft skill menunjukkan kepekaan, intuisi sumber daya manusia. Hard skill mencerminkan pengetahuan dan keterampilan fisik sumber daya manusia. Social skill menunjukkan keterampilan dan hubungan sosial sumber daya manusia dengan manusia disekitarnya. Sedangkan mentality skill menunjukkan mental sumber daya manusia. Peningkatan kompetensi dapat dilakukan melalui program pendidikan dan pelatihan .Kompetensi pegawai antara lain tercermin melalui pengetahuan. Sedangkan pengetahuan di peroleh melalui pendidikan formal.

Berdasarkan latar belakang yang diuraikan secara teorits, maka perlu dikaji lebih rinci melalui penelitian empiris guna mendukung hasil penelitianmengenai pengaruh kompensasi dan kompetensi Terhadap kinerja karyawan PT. Herfinta Aek Batu kecamatan Torgamba Kabupaten Labuhanbatu Selatan.

\section{Rumusan Masalah}

Berdasarkan uraian latar belakang penelitian akan dirumuskan permasalahan dalam penelitian yaitu : 
1. Apakah kompensasi berpengaruh signifikan terhadap kinerja karyawan PT. Herfinta Aek Batu Kecamatan Torgamba Kabupaten Labuhanbatu Selatan

2. Apakah kompentensi berpengaruh signifikan terhadap kinerja karyawan PT. Herfinta Aek Batu Kecamatan Torgamba Kabupaten Labuhanbatu Selatan

3. Apakah kompensasi dan kompetensi secara simultan berpengaruh signifikan terhadap kinerja karyawan PT. Herfinta Aek Batu Kecamatan Torgamba Kabupaten Labuhanbatu Selatan.

\section{Tujuan Penelitian}

Penelitian ini bertujuan sebagai berikut :

1. Untuk mengetahui pengaruh kompensasi terhadap kinerja karyawan PT. Herfinta Aek Batu Kecamatan Torgamba Kabupaten Labuhanbatu Selatan.

2. Untuk mengetahui pengaruh kompetensi terhadap kinerja karyawan PT. Herfinta Aek Batu Kecamatan Torgamba Kabupaten Labuhanbatu Selatan.

3. Untuk mengetahui pengaruh kompensasi dan kompetensi secara simultan terhadap kinerja karyawan PT. Herfinta Aek Batu Kecamatan Torgamba Kabupaten Labuhanbatu Selatan.

\section{KAJIAN TEORI}

\section{KOMPENSASI}

Masalah kompensasi merupakan masalah yang sangat penting, karena kompensasi merupakan dorongan utama seseorang menjadi pegawai. Kompensasi terdiri dari kompensasi finansial dan kompensasi non finansial. Kompensasi yang digunakan secara benar dapat mendorong semangat karyawan untuk bekerja.

Menurut Hariandja (2005), Kompsnsasi adalah keseluruhan balas jasa yang diterima oleh pegawai sebagai akibat dari pelaksanaan pekerjaan di organisasi dalam bentuk uang atau lainnya, yang dapat berupa gaji, upah, bonus, insentif, dan tunjangan hari raya, uang makan, uang cuti, dan lain-lain.

Menurut Sedarmayanti (2012), kompensasi menurut Sedarmayanti adalah segala sesuatu yang diterima oleh karyawan sebagai balas jasa kerja mereka.

Dari defenisi diatas dapat disimpulkan bahwa kompensasi merupakan bentuk penghargaan atau balas jasa yang diberikan oleh perusahaan kepada karyawannya baik yang berbentuk financial maupun barang dan jasa pelayanan agar karyawan merasa dihargai dalam bekerja.

\section{KOMPETENSI}

Menurut Hutapea dan Thoha (2008), Kompetensi adalah kemampuan dan kemauan dalam melakukan sebuah tugas dengan kinerja yang efektif dan efisien untuk mencapai tujuan perusahaan.

Menurut Wibowo (2012), Kompetensi adalah suatu kemampuan untuk melaksanakan suatu pekerjaan yang dilandasi atas keterampilan dan pengetahuan serta didukung oleh sikap kerja yang dituntut oleh pekerjaan tersebut.

Berdasarkan pengertian tersebut dapat disimpulkan bahwa kompetensi adalah kemampuan dalam kerja dengan mengintegrasikan pengetahuan, kemampuan, keterampilan serta nilai-nilai pribadi berdasarkan pengalaman dan pembelajaran dalam rangka pelaksanaan tugasnya secara professional, efektif dan efisien.

\section{KINERJA}


Mangkunegara (2009), berpendapat bahwa kinerja (prestasi kerja) adalah hasil kerja secara kualitas dan kuantitas yang dicapai oleh seorang pegawai dalam melaksanakan tugasnya sesuai dengan tanggung jawab yang diberikan kepadanya .

Suwatno (2011), juga berpendapat bahwa kinerja atau prestasi kerja merupakan hasil yang dicapai seseorang menurut ukuran yang berlaku, dalam ukuran waktu tertentu, berkenaan dengan pekerjaan serta perilaku dan tindakannya.

\section{METODE PENELITIAN}

Pada penelitian ini menggunakan metode deskriptif dan analisis kuantitatif. Selanjutnya yang digunakan adalah data primer dan data skunder. Penelitian ini diawali dengan mengumpulkan data sekunder yaitu dengan melakukan studi literature yang mencakup kajian teori, penelitian sebelumnya dan model yang berkaitan dengan masalah yang diperoleh dari perpustakaan dan internet. Kemudian dilanjutkan dengan pengumpulan data primer melalui kuesioner dari responden yang merupakan karyawan PT.Herfinta Aek Batu Kecamatan Torgamba kabupaten Labuhanbatu Selatan.

\section{METODE ANALISIS DATA}

\section{Analisis Regresi Linier Berganda}

Analisis regrasi linier berganda bertujuan untuk mengetahui hubungan linier antara beberapa variabel bebas dengan variabel terikat. Analisis linier beganda dapat dirumuskan sebagai berikut :

$$
\begin{aligned}
& \mathrm{Y}=\mathrm{a}+\mathrm{b}_{1} \mathrm{X}_{1}+\mathrm{b}_{2} \mathrm{X}_{2}+\mathrm{e} \\
& \text { Dimana : } \\
& \mathrm{Y} \quad=\text { kenirja karyawan } \\
& \mathrm{X}_{1}=\text { kompensasi } \\
& \mathrm{X}_{2}=\text { kompetensi } \\
& \mathrm{b}_{1} \mathrm{~b}_{2}=\text { koefisien arah regresi } \\
& \mathrm{e} \quad=\text { standart Eror }
\end{aligned}
$$

Pengujian hipotesia dilakukan dengan signifikan secara parsial (uji-t) signifikan secara simultan (uji-f) dan pengujian koefisien determinasi $\left(\mathrm{R}^{2}\right)$ yaitu sebagai berikut :

a. Uji Signifikan secara parsial (uji-t)

(Uji-t) adalah uji yang menunjukan seberapa jauh pengaruh satu penjelasan variabel penjelasasn individu dalam menenrangkan variasi variabel terikat.

Apabila nilai signifikan t lebiih kecil dari a $=0,05$ maka dapat diketahui variabel bebasnya memberikan pengaruh yang nyata terhadap variabel terkaitnya.

Penelitian menguji hipotesis yang diajukan diterima atau ditolak dengan menggunakan uji statistik $\mathrm{t}$ ( $\mathrm{t}$ test ). Jika hitung < tabel maka $\mathrm{H} 0$ diterima dan $\mathrm{H} 2$ ditolak, jika thitung $>$ $\mathrm{t}_{\text {tabel }}$ maka $\mathrm{HO}$ ditolak Ha diterima.

b. Uji signifikan secara simultan uji ( uji-F)

Uji $\mathrm{F}$ pada dasaarnya mengajukan apakah semua variabel bebas yang dimasukkan dalam model mempunyai pegaruh secara bersama-sama terhadap variabel terikat. Uji secara simultan (uji-F) dilakukan bertujuan untuk mengetahui apakah variabel-variabel bebas bersama-sama memiliki pengaruh yang nyata terhadap variabel dependen di uji dengan tingkat kepercayaan (confidence interval) 95\% atau a $=5 \%$.

Dalam menguji hipotesis yang diajukan diterima atau ditolak dapat menggunakan uji statistik F (uji f).

c. Koefisien Determinasi $\left(\mathrm{R}^{2}\right)$ 
Identifikasi determinasi ( $\mathrm{R}^{2}$ ) digunakan untuk melihat seberapa besar pengaruh variabel-variabel independen (X) Terhadap variabel dependen (Y). Dalam output SPSS, koefisien determinasi terletak pada tabel Model Summary dan tertulis R square. Namun untuk regresi linier berganda sebaiknya menggunakan Adjusted $R$ square, karena disesuaikan dengan jumlah variabel independenyang digunakan dalam penelitian. Nilai R square dikatakan baik jika diatas 0,5 karena nilai $\mathrm{R}$ square berkisar antara 0 sampai 1.

\section{HASIL PENELITIAN}

\section{Hasil Analisis Regresi Linier Berganda}

Analisis regresi linier berganda bertujuan untuk mengetahui pengaruh dari variabel-variabel independen terhadap variabel dependen, dapat dilihat pada tabel berikut ini

\section{Tabel}

\section{Hasil Regresi Linier Berganda}

\begin{tabular}{|c|c|c|c|c|c|}
\hline \multirow[t]{2}{*}{ Model } & \multicolumn{2}{|c|}{$\begin{array}{l}\text { Unstandardized } \\
\text { Coefficients }\end{array}$} & $\begin{array}{l}\text { Standardized } \\
\text { Coefficients }\end{array}$ & \multirow[t]{2}{*}{$t$} & \multirow[t]{2}{*}{ Sig. } \\
\hline & B & Std. Error & Beta & & \\
\hline $\begin{array}{l}\text { (Constant) } \\
\text { Kompensasi } \\
\text { Kompetensi }\end{array}$ & $\begin{array}{l}5,340 \\
, 594 \\
, 464\end{array}$ & $\begin{array}{l}2,915 \\
122 \\
137\end{array}$ & $\begin{array}{l}, 558 \\
, 389\end{array}$ & $\begin{array}{l}1,832 \\
4,854 \\
3,388\end{array}$ & $\begin{array}{l}, 076 \\
, 000 \\
, 002\end{array}$ \\
\hline
\end{tabular}

\section{a.Dependent Variable : Kinerja Karyawan}

Model yang digunakan untuk menduga pengaruh tersebut adalah : $\mathrm{Y}=5,340+0,594 \mathrm{X}_{1}+0,464 \mathrm{X}_{2}$

\section{Keterangan :}

1. Koefisien regresi konstanta sebesar 5,340 mempunyai arti jika ada atau variabel kompensasi dan kompetensi, maka kinerja karyawan akan sebesar 5,340. 
2. Koefisien regresi kompensasi sebesar 0,594 mempunyai arti bahwa setiap terjadi penambahan kompensasi sebesar 0,594 maka kinerja karyawan sebesar 1 kali.

3. Koefisien regresi kompetensi sebesar 0,464 mempunyai arti bahwa setiap terjadi pengurangan kompetensi sebesar 0,464 maka kinerja karyawan sebesar 1 kali.

\section{PEMBAHASAN}

Hasil persamaan regresi linear berganda menunjukan hasil bahwa variabel kompensasi (X1) dan kompetensi (X2) bernilai positif terhadap kinerja. Artinya apabila variabel kompensasi dan kompetensi ditingkatkan, maka akan meningkatkan pula kinerja karyawan PT. Herfinta Aek Batu Kecamatan. Torgamba Kabupaten. Labuhanbatu Selatan.

Penjelasan dari masing-masing pengaruh variabel dapat dijelaskan sebagai berikut :

a. Hubungan Kompensasi $\left(\mathrm{X}_{1}\right)$ terhadap kinerja $(\mathrm{Y})$

Berdasarkan hasil pengujian hipotesis $(\mathrm{H} 1)$ telah membuktikan terdapat pengaruh antara kompensasi terhadap kinerja. Melalui hasil perhitungan yang telah dilkakukan diperoleh nilai t hhitung 4,854 dengan signifikan sebesar 0,000. Dalam hal ini berarti kompensasi merupakan dorongan utama seseorang menjadi karyawan.

Hasil diatas menyatakan bahwa Hipotesis pertama yang diduga kompensasi mempunyai pengaruh yang positif dan signifikan terhadap kinerja karyawan PT Herfinta Aek Batu Kecamatan. Torgamba Kabupaten. Labuhanbatu Selatan diterima.

b. Hubungan Kompetensi $\left(\mathrm{X}_{2}\right)$ terhadap kinerja (Y)

Berdasarkan hasil pengujian hipotesis $\left(\mathrm{H}_{2}\right)$ telah membuktikan terdapat pengaruh antara kompetensi terhadap kinerja karyawan. Melalui hasil perhitungan yang telah dilakukan diperoleh nilai t hitung sebesar 3,388 dengan signifikansi sebesar 0,002. Dalam hal ini berarti dengan adanya kompetensi maka karyawan dapat mengasah kemampuannya dalam kerja dengan mengintegrasikan pengetahuan, kemampuan, keterampilan serta nilai-nilai pribadi berdasarkan pengalaman dan pembelajaran dalam rangka pelaksanaan tugasnya secara professional, efektif dan efisien.

Hasil diatas menyatakan bahwa Hipotesis pertama yang diduga kompetensi mempunyai pengaruh yang positif dan signifikan terhadap kinerja karyawan PT. Herfinta Aek Batu Kecamatan. Torgamba Kabupaten. Labuhanbatu Selatan diterima .

\section{KESIMPULAN}

Berdasarkan hasil penelitian dan interprestasi pembahasan yang dilakukan, maka diperoleh kesimpulan pada penelitian ini sebagai berikut :

1. Variabel Kompensasi secara parsial memiliki pengaruh paling dominan Terhadap kinerja karyawan.

2. Variabel Kompetensi secara parsial memilik pengaruh Terhadap kinerja karyawan.

3. Variabel Kompensasi dan Kompetensi secara serempak memiliki pengaruh Terhadap kinerja karyawan.

\section{SARAN}

Berdasarkan hasil analisis dan kesimpulan penelitian, maka dianjurkan beberapa saran sebagai berikut :

1. Kebijaksanaan waktu pembayaran kompensasi hendaknya berpedoman dari pada menunda, lebih baik mempercepat dan menentukan waktu yang paling tepat. Waktu pemberian kompensasi yang paling tepat akan memberikan dampak yang positif bagi pegawai dan organisasi. 
2. Sebaiknya penempatan pegawai di masing-masing bidang sesuai dengan keahlian dan pendidikan yang mereka miliki agar pekerjaan lebih efektif dan efisien, yang juga akan berpengaruh pada keberhasilan organisasi.

\section{DAFTAR PUSTAKA}

Hariandja, Marihot T.E.2005,Manajemen Sumber Daya manusia, Jakarta : Grasindo

Sedarmayanti 2012, Manajemen dan Komponen Terkait Lainnya. Bandung : Refika Aditama

Hutapea, P. dan Thoha, N .2008, Kompetensi Plus. Gramedia Pustaka Utama: Jakarta.

Wibowo 2012, Manajemen Kinerja. Edisi Ketiga. Jakarta : PT. Raja Grafindo Persada

Mangkunegara, Anwar Prabu . 2009. Manajemen Sumber Daya Manusia. Bandung: Remaja Rosdakarya

Suwatno 2011, Manajemen Sumber Daya Manusia. Jakarta Erlangga 